Scientific journal

PHYSICAL AND MATHEMATICAL EDUCATION

Has been issued since 2013 .

Науковий журнал

ФІЗИКО-МАТЕМАТИЧНА ОСВІТА

Видається з 2013.
ISSN 2413-158X (online)
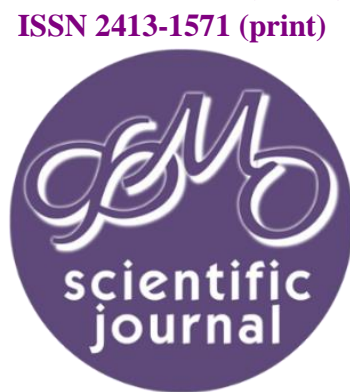

http://fmo-journal.fizmatsspu.sumy.ua/

Коновал О.А. Дискусійні задачі в традиційній методиці навчання електродинаміки. Фізико-математична освіта. 2018. Випуск 1(15). С. 113-117.

Konoval O. Debatable Tasks In The Traditional Method Of Electrodynamics Teaching. Physical and Mathematical Education. 2018. Issue 1(15). P. 113-117.

Удк 378.016: 537.8

O.A. Konoval

Kryvyi Rih State Pedagogical University, Ukraine konovaloa@gmail.com

DOI 10.31110/2413-1571-2018-015-1-019

\title{
DEBATABLE TASKS IN THE TRADITIONAL METHOD OF ELECTRODYNAMICS TEACHING
}

Abstract. The article deals with the theoretical analysis of the traditional approaches to electrodynamics teaching. The author has paid attention to the contradictions arising in the process of application of the classical Biot-Savart's law and the neutrality conditions of the conductor with a constant current. It is foremost marked that there are different points of view as for the status of Biot-Savart's law, which is unacceptable during interpretation of the electrodynamic phenomena and at the study of electrodynamics by future physics teachers. Contradictions to principle of relativity, arising at joint application of Biot-Savart and Coulomb's laws are described and analysed in detail. These contradictions arise as a result of the fact that in the analysis of electromagnetic phenomena the relativistic correction in the expression of the intensity of the electric field of a uniformly mobile charged particle is neglected. Despite of the meagerness of the magnitude of such an amendment, it should be taken into account for the correct and adequate description of the phenomena.

Three neutrality conditions of the conductor with a constant current proposed in the scientific and methodological literature are discussed. It is shown that a traditional neutrality condition of the conductor with a constant current $\rho_{+}^{0}=-\rho_{-}^{0}\left(1-\beta^{2}\right)^{-1 / 2}=-\rho_{-}$, where $\rho_{-}=\rho_{-}^{0}\left(1-\beta^{2}\right)^{-1 / 2}$ is charge density of the conduction electrons in the reference system (RS) $\mathrm{K}$

$; v$ is the drift velocity of the conduction electrons; $\beta=\frac{v}{c}$; $c$ is the speed of light in vacuum; $\rho_{-}^{0}, \rho_{+}^{0}$ are the charge densities of the conduction electrons and positive ions, respectively, in their own reference systems, is inconsistent and contradicts to principle of relativity. The noncontradictory neutrality condition of the conductor with a constant current is offered.

The conclusion about some limited nature of traditional teaching methods of electrodynamics is drawn. Biot-Savart's law and the formula $\vec{E}=q \vec{r} / 4 \pi \varepsilon_{0} r^{3}$ (which is obviously a consequence of Coulomb's law) are not compatible for simultaneous use in the analysis of the same electrodynamic problem because they lead to principally false conclusions and contradictions. At the same time in standard textbooks and scientific and methodological publications these two formulas are used together, which is, from our point of view, the physical error.

Key words: Biot-Savart's law, neutrality condition of the conductor with a constant current, teaching methods of electrodynamics, principle of relativity.

The problem setting. Reference to the modern theoretical physics study-aids, general physics and school course of physics shows that in the methods of teaching electrodynamics during interpretation of certain laws there are contradictions and questions for discussion, which prevent the formation of students` holistic picture of adequate ideas about the system of electrodynamics fundamental laws.

Analysis of the latest research. Taking into consideration the limited volume of scientific article we shall concentrate more in detail on the analysis of a number of contradictions, related to Biot-Savart's law and the condition of neutrality of a metal conductor with a constant current $[1 ; 2]$, leaving more thorough investigation of the causes of other contradictions and questions for discussion, taking place in the theory and methodology of electrodynamics study as the prospect of further research. First of all let's note the ambiguity in the interpretation of the status of Biot-Savart's law. From the review, presented by us in the monograph [2, p. 98], we have 7 points of view as for the status of Biot-Savart's law. Savart’s law

Let us pay attention to a number of contradictions which are associated with the interpretation and application of Biot-

$$
d \vec{B}=\frac{\mu_{0}}{4 \pi} \cdot \frac{i \cdot[d \vec{l}, \vec{r}]}{r^{3}} .
$$


Despite understanding the fact that the law (1) in principle is unavailable to direct experimental verification, in the vast majority of modern textbooks Biot-Savart's law is interpreted as an experimental law.

But the analysis of the essence of this law and historical sources testifies about the incorrectness of such approach for the study and interpretation of the ratio of (1) [2].

The purpose of the article. In connection with this the purpose of the article is to carry out a theoretical analysis of modern methodological approaches in electrodynamics teaching, to reveal the contradictions and problems in the electrodynamics itself and in the methods of teaching electrodynamics and to determine the prospects for their refutation.

Statement of the basic material. Our study has shown that in some cases the application of the law (1) leads to the results that are contrary to the main postulates of the relativistic electrodynamics.

Then from (1) and the superposition principle we can conclude that the expression for magnetic field (MF) induction, which is created by a moving charged particle (CP) is $[2 ; 5 ; 8]$,

$$
\vec{B}_{1}=\frac{\mu_{0} q}{4 \pi r^{3}} \cdot[\vec{v}, \vec{r}]=\mu_{0} \varepsilon_{0}\left[\vec{v}, \frac{q \vec{r}}{4 \pi \varepsilon_{0} r^{3}}\right]=\mu_{0} \varepsilon_{0}[\vec{v}, \vec{E}],
$$

where $\vec{E}=q \vec{r} / 4 \pi \varepsilon_{0} r^{3}$ is the strength of the electric field created by (in the non-relativistic approximation) a mobile CP at the corresponding point of the field, $\vec{v}$ is the drift velocity of the conduction electrons.

But, the use of the expression (2) and $\vec{E}=q \vec{r} / 4 \pi \varepsilon_{0} r^{3}$ for the analysis of the same electrodynamic problem leads to the conclusions that contradict the principle of relativity.

Indeed, let's consider a thought experiment, shown schematically in Fig. 1

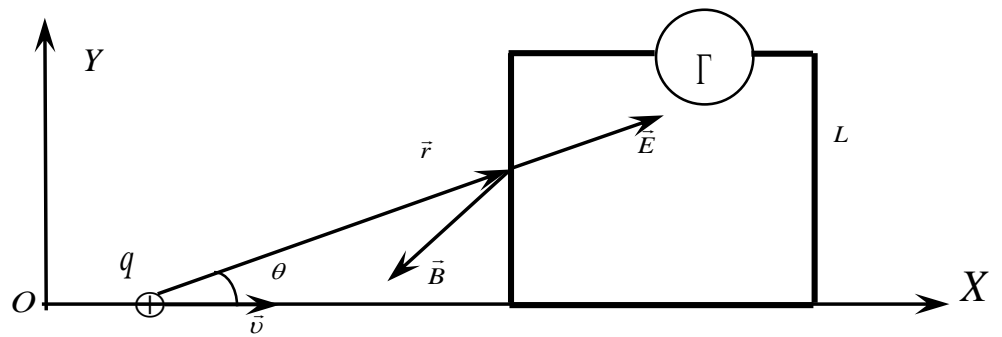

Fig. 1. The scheme of a thought experiment to determine the EMF of induction in the loop $L . C P$ is moving with constant speed $\vec{v}$ in the plane of the loop.

According to the traditional interpretation of the phenomenon of electromagnetic induction, in the loop $L$, due to time changes in the magnetic field at each point of a flat surface bounded by the loop $L$ (and therefore the change of the magnetic flux in time), there will be EMF of induction. But this conclusion contradicts the principle of relativity: with the transition to the reference frame associated with $\mathrm{CP}$, the loop $L$ will be moving in a centrally symmetric Coulomb field.

Such field is a potential one, so there are no physical reasons that could generate voltage in the loop $L$. Hence the use of the law (1) and its equivalent - the expression for MF induction, which is generated by a separate mobile CP $\vec{B}_{1}=\varepsilon_{0} \mu_{0}[\vec{v}, \vec{E}]=\frac{\mu_{0} q \cdot[\vec{v}, \vec{r}]}{4 \pi r^{3}}$ - in such problems gives the result that contradicts the physical reality.

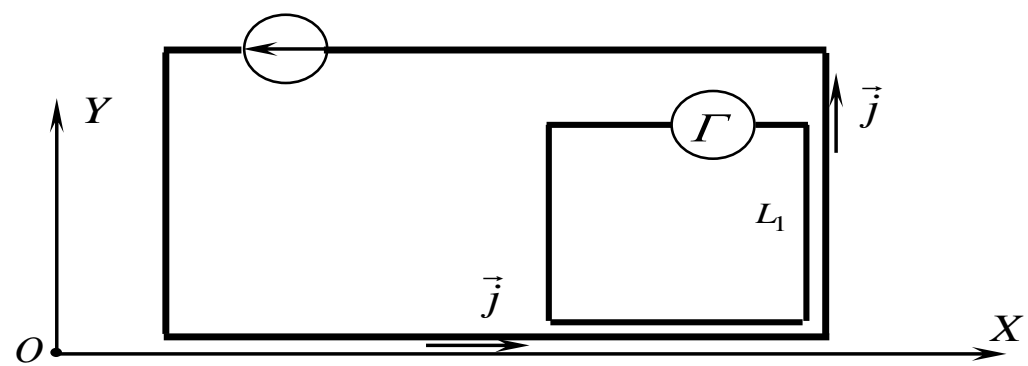

Fig. 2. In the wire loop $L_{1}$ which is located next to the DC circuit EMF is absent

Similarly, in the problem shown in Fig. 2 the use of the classical Biot-Savart`s law leads to the result that is contrary to the principle of relativity.

According to Biot-Savart's law (1) and the traditional interpretation of the phenomenon of EMI (see the problems, shown in Fig. 2) we should expect a certain EMF of induction in the loop $L_{1}$.

This conclusion follows from the following considerations.

Each of the conduction electrons, moving with the drift velocity in the conductors of the electric circuit creates alternating magnetic field at each point of the flat surface bounded by the loop $L_{1}$. In its turn this alternating magnetic field creates a vortex electric field at each point of the surface bounded by the loop ( $\operatorname{rot} \vec{E} \neq 0$ ). 
Integral effect should manifest itself in the emergence of induced current in the loop $L_{1}$. But experiments show that the voltage in the circuit does not emerge.

Now let us turn to the analysis of another bright contradiction existing in the methodology of studying electrodynamics. Historically in educational literature the discussion of space charge of the conductor with constant current (CCC) (or in other words the condition of neutrality CCC) was suggested in R.Feynman`s manual [1]. The problem of interaction of CCC and a charged particle moving along CCC is analyzed.

Let a cylindrical line metal conductor with constant current (CCC) be located along the axis of the reference system (RS) $K$ (Fig. 3).

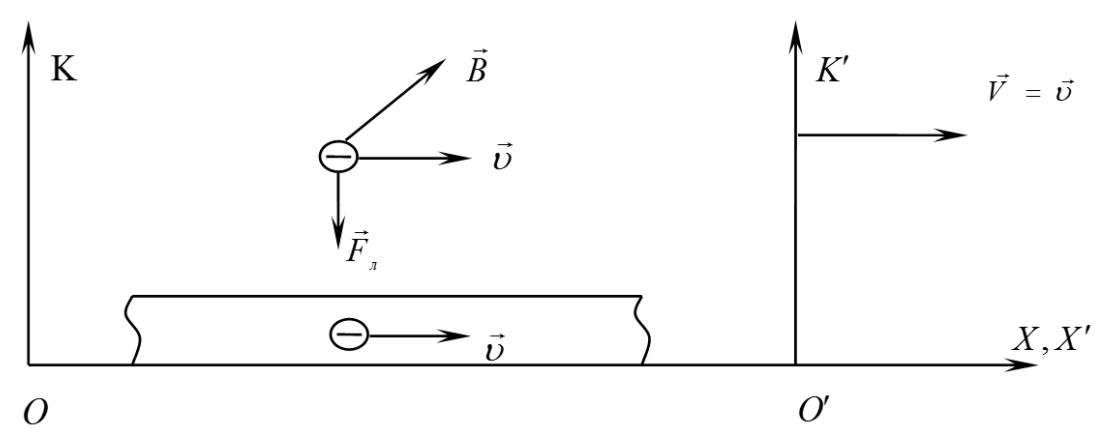

Fig. 3. The interaction of the electron and the CCC in the RS $K$ and RS $K^{\prime}$.

Then it is obvious that the current density $j_{x}=\rho_{-} \cdot v$, where $\rho_{-}=\rho_{-}^{0}\left(1-\beta^{2}\right)^{-1 / 2}$ is charge density of the conduction electrons in the reference system (RS) $K, \beta=\frac{v}{c}, c$ is the speed of light in vacuum, $\rho_{-}^{0}, \rho_{+}^{0}$ are the charge densities of the conduction electrons and positive ions, respectively, in their own reference systems, $v$ is the drift velocity of the conduction electrons .

The common condition of CCC neutrality is $[1 ; 5 ; 6]$ :

$$
\rho_{+}^{0}=-\rho_{-}^{0}\left(1-\beta^{2}\right)^{-1 / 2}=-\rho_{-} .
$$

Let's assume for simplicity that the rate of RS $K^{\prime}$ is numerically equal to the velocity of conduction electrons $V=v$.

Then in terms of RS $K^{\prime}$ the CCC will be characterized by a bulk density of the charge

$$
\rho^{\prime}=\rho_{+}^{\prime}+\rho_{-}^{\prime}=\frac{\rho_{+}^{0}}{\sqrt{1-\beta^{2}}}-\rho_{-} \sqrt{1-\beta^{2}}=\frac{\rho_{+}^{0} \beta^{2}}{\sqrt{1-\beta^{2}}} .
$$

Perhaps G.V.Nikolaev was the first to point out the contradiction of neutrality condition (3) in his work [7]: as RS $K^{\prime}$ and RS $K$ are equivalent, thanks to the symmetric conditions that determine the motion of electrons and protons in the RS $K^{\prime}$ and RS $K$ respectively, the physical situations in these reference systems should be the same.

There are three ways to solve this contradiction in the scientific and methodological literature:

Method 1. "... Physical properties of negative and positive charges are different" [7]. But if the electron and proton in electromagnetic interactions manifest themselves symmetrically, "we have to recognize the existence of physical nonequivalence fixed on the surface of a solid (creating a gravitational field) body of the Earth laboratory RS with respect to any other RS which moves relatively to it" $[7$, p. 6].

Method 2. Current-carrying conductor is neutral in the RS, which is moving with the drift velocity of the conduction electrons [8, p. 92], that is, in the RS $K^{\prime}$ :

$$
\rho^{\prime}=\rho_{+}^{\prime}+\rho_{-}^{\prime}=0 \text {. }
$$

The argument of the authors [23] is as follows. Assume the appearance of the space charge of current conductor in the RS $K^{\prime}$ and consider the interaction of conduction electrons of CCC with the field of this space charge. In the RS $K$ their movement creates a current density $\rho_{-} \vec{v}$. Since in the RS $K^{\prime}$ magnetic field does not effect on conduction electrons and "there is no second force that could counterbalance the effect of the electric field of the space charge" $[8, p .91]$ the performance should be required (5).

Method 3. Neutrality condition of the conductor proposed by us $[9 ; 10]$ :

$$
\rho_{+}^{0}=-\rho_{-}^{0} \text {. }
$$

Then, in the RS $K$ fixed current-carrying conductor is characterized by a bulk density of the charge:

$$
\rho=\rho_{+}^{0}-\frac{\rho_{-}^{0}}{\sqrt{1-\beta^{2}}}=\frac{\rho_{0}}{\sqrt{1-\beta^{2}}}\left(\sqrt{1-\beta^{2}}-1\right) .
$$

We'll present arguments in favor of (6) and (7):

a) In fact, if with the flow of current the condition (3) $\rho_{+}^{0}=-\rho_{-}$, this means that $\rho_{-}^{0}<\frac{\rho_{-}^{0}}{\sqrt{1-\beta^{2}}}=\rho_{-}$. 
That is, the density of the charge of motionless as a whole collection of the conduction electrons is less than the density of the charge of the same set of mobile electrons.

Then, when $\beta=0$ (there is no current in the conductor) $\rho_{-}^{0}=\rho_{-}<\rho_{+}^{0}$, that is a conductor without current (after the current is switched off) will be positively charged: $\rho_{+}^{0}-\rho_{-}^{0}=\rho_{+}^{0}\left(1-\sqrt{1-\beta^{2}}\right)$, at that the magnitude of the charge depends on the current flowed earlier [9]!

b) The density of any charge distribution in the transition from one RS to another is converted by the formula $\rho=\rho^{0}\left(1-\frac{V^{2}}{c^{2}}\right)^{-1 / 2}$, where $V$ is the velocity of some charge distribution with density $\rho^{0}, \rho$ being charge density in the RS with respect to which this charge distribution is moving. Therefore, the total charge density of electrons and ions moving with arbitrary but identical speed should be increased in one and the same number of times. If the conductor without current is neutral $\rho_{+}^{0}=-\rho_{-}^{0}$ (that is natural), then why, after the current appears and the set of electrons moving at the speed $v$, is described, as it is known, by the charge density $\rho_{-}=\rho_{-}^{0}\left(1-\beta^{2}\right)^{-1 / 2}$, the density $\rho_{-}$does not become larger in absolute value than $\rho_{+}^{0}$ ?

c) If the total density of electrons and ions moving at the same speed change equally, the conductor without current that moves (assuming neutrality (3)) will be charged with a bulk density [9;10]:

$$
\rho=\rho_{+}-\rho_{-}=\frac{\rho_{+}^{0}}{\sqrt{1-\beta^{2}}}\left(1-\sqrt{1-\beta^{2}}\right) !
$$

But there is no physical reasons to consider a fixed (like the one that moves at constant speed) conductor without current charged;

d) The current density in the RS $K$ is $j_{x}=\rho_{-} \cdot v$. And in the RS $K^{\prime}$ the current is only caused by the travel of ions moving at the same speed as the conductivity electrons in the RS $K$. However, the current density in the RS $K^{\prime}$ is more than $j_{x}^{\prime}=\rho_{+}^{0} v\left(1-\beta^{2}\right)^{-1 / 2}>j_{x}$, despite the fact that the charge density of electrons and ions grow similarly in the RS with respect to which they move at equal speed.

Similarly, we 'll find that the magnetic field the RS $K^{\prime}$ is larger than in the RS $K: B_{z}^{\prime}=\frac{B_{z}}{\sqrt{1-\beta^{2}}}$, but physical situations are identical (up to a sign of moving and stationary charged particles). So again we state the contradiction;

e) Taking into consideration the condition of neutrality of the current conductor (3) we can conclude the following:

- in the RS $K$ there is no electric field, and in the RS $K^{\prime}$ the electric field intensity is: $E_{y}^{\prime}=\frac{\rho_{-} S \beta^{2}}{2 \pi \varepsilon_{0} a \sqrt{1-\beta^{2}}}$, where $a$ is the distance from the point of the field to the linear guide;

- the magnetic field induction in the RS $K$ is $B_{z}=\frac{\mu_{0} \rho_{-} v \cdot S}{2 \pi a}$, and in the RS $K^{\prime}$ the induction of the magnetic field is $\left(1-\beta^{2}\right)^{-1 / 2}$ times more, because $I^{\prime}=I\left(1-\beta^{2}\right)^{-1 / 2}$, despite the fact that in the RS $K^{\prime}$ the ions move with the same speed (in magnitude) as the conductivity electrons in the RS $K$;

f) Violation of physical relativity in the transition from RS $K$ to RS $K^{\prime}$ can be seen most clearly by comparing the forces acting on the electron in the RS $K$ (its speed is $v$ ) and positron moving at the speed $v^{\prime}=v$ along the current in the RS $K^{\prime}$.

The traditional point of view as for the force acting on the electron is equal to the expression $q v \cdot B_{z}$, and the force acting on the positron in the RS $K^{\prime}$ is

$$
q v \cdot B_{z}^{\prime}-q E_{y}^{\prime}=0,
$$

although the physical conditions in the systems $K$ and $K^{\prime}$ are the same [2]. In this example the possibility of physical adaptation, which "is crucial condition for the implementation of physical relativity" is probably violated [11, p. 8-9].

Conclusions. Biot-Savart's law and the formula $\vec{E}=\frac{q \vec{r}}{4 \pi \varepsilon_{0} r^{3}}$ (which is obviously a consequence of Coulomb's law) are not compatible for simultaneous use in the analysis of the same electrodynamic problem because they lead to principally false conclusions and contradictions.

Thus, the traditional method of studying electrodynamics, based, in particular, on the classical Biot-Savart's law can not explain the absence of voltage in the loop $L_{1}$ in Figures 1, 2. At the same time in standard textbooks and scientific and methodological publications these two formulas are used together, which is, from our point of view, the physical error.

We realize that our reasoning isn't faultless. But the fact is that there are objective contradictions and it is desirable that they should become a subject of scientific and methodical discussion. The assumed result could be focused on elimination of problem questions in the methodology of electrodynamics teaching, and, ultimately, could have a positive impact on the quality of students' understanding dialectics, the importance and role of theoretical and empirical methods in physics and methods of its teaching. 


\section{References}

1. Feynman R. Feynmanovskie lektsii po fizike [Feynman lectures on Physics]:v 9 t. // R. Feynman, R. Leighton, M. Sands. - T.5 : Elektrichestvo i magnetism [Electricity and magnetism]. M: Mir, 1966. $290 \mathrm{~s}$. (in Russian)

2. Konoval O.A. Teoretychni ta metodychni osnovy vyvchennya elektrodynamiky na zasadah teorii vidnosnosti : monografiya [Theoretical and methodological fundamentals of Electrodynamics studying on the base of the theory of relativity] // O.A.Konoval ; Ministerstvo osvity i nauky Ukrainy; Kryvorizky derzhavny pedagogichny universytet. Kryvyy Rig : Vydavnychy dim, 2009. 346 s. (In Ukrainian).

3. Irodov I. E. Elektromagnetizm. Osnovnyye zakony [Electromagnetism. The main laws ] / I. E. Irodov [4-e Izd., ispr.]. M. : BINOM. Laboratoriya znaniy, 2003. 320 s. (in Russian)

4. Konoval O.A.Osnovy elektrodynamiky [Fundamentals of Electrodynamics] : navch. posib. dlya stud. vysch. ped. navch. zakl. // O.A.Konoval ; Ministerstvo osvity i nauky Ukrainy; Kryvorizky derzhavny pedagogichny universytet. Kryvyy Rig : Vydavnychy dim, 2008. 347 s. (In Ukrainian)

5. Ugarov V.A. Spetsialnaya teoriya otnositelnosti [Special theory of relativity] // V. A. Ugarov. M : Nauka, 1977. 384 s. (in Russian)

6. Becker R. Elektronnaya teoriya [Electronic theory ] // R. Becker. L. : ONTI, 1936. 416 s. (in Russian)

7. Nikolaev G.V. Paradoks Feynmana i asimmetriya laboratornoy I dvizhuscheysya sistem otscheta [Paradox of Feynman and asymmetry of the laboratory and moving frames of reference] // G.V. Nikolaev. M. , 1975 . 20 s. Statya dep. v VINITI , reg. № 1937-75. (in Russian)

8. Martinson M.L. O plotnosti zaryada vnutri provodnika s tokom [On the density of the charge inside the conductor with a current] // ML Martinson, A.V. Nedospasov // Uspehi fizicheskih nauk [Successes of Physical sciences]. 1993. V. 163 . № 1. S. 91-92 . (in Russian)

9. Konoval O. A. Elektrychne pole providnyka zi strumom [ Electrical field of the conductor with a current ]. Dydaktyka dystcyplin fizyko-matematychnoi ta tehnologichnoi osvitnih galuzey [Didactics of the disciplines of Physics and Mathematics and technological educational branches ]: Zbirnyk nauk. pr. Kamianets-Podilskogo derzh. ped. un-tu. Seriya pedagogichna. Kamianets-Podilsky : K- PDPU, inf. vyd.vid., 2002. Vyp . 8. S. 265-275. (In Ukrainian).

10. Konoval O. A Osnovy spetsialnoi teorii vidnosnosti [Fundamentals of special theory of relativity] navch.-metod. posib. dlya samost. rob. stud. vyshch. ped. navch. zakl. / O. A. Konoval ; KPI DVNZ «KNU». Kryvyy Rig: Vyd. R.A. Kozlov, 2014. 272 s. (In Ukrainian).

11. Fock V.A. Teoriya Einsteina I fizicheskaya otnositelnost [Einstein's theory and physical relativity] // V.A.Fock. M.: Znanie, 1967. 45s. (in Russian)

\section{ДИСКУСІЙНІ ЗАДАЧІ В ТРАДИЦІЙНІЙ МЕТОДИЦІ НАВЧАННЯ ЕЛЕКТРОДИНАМІКИ О.А. Коновал}

Криворізький державний педагогічний університет, м. Кривий Ріг, Україна

Анотація. У статті здійснено теоретичний аналіз традиційних підходів до вивчення електродинаміки. В статті звернута увага на протиріччя, що виникають при застосуванні класичного закону Біо-Савара і вибору умови нейтральності провідника з постійним струмом. Перш за все наголошено на існуванні різних точок зору щодо статусу закону Біо-Савара, що є неприйнятним при інтерпретації електродинамічних явищ й при вивченні електродинаміки майбутніми вчителями фізики. Детально проаналізовані суперечності з принципом відносності, що виникають при сумісному застосуванні закона Біо-Савара та закону Кулона. Ці суперечності виникають внаслідок того, що при аналізі електромагнітних явищ нехтують релятивістською поправкою у виразі напруженості електричного поля рівномірно рухомої зарядженої частики. Незважаючи на мізерність величини такої поправки ії слід враховувати обов'язково для коректного та адекватного опису явищ.

Обговорюються, запропоновані в науково-методичній літературі, три умови нейтральності провідника, по якому протікає постійний струм. Показано, що загальноприйнята умова нейтральності провідника з постійним струмом $\rho_{+}^{0}=-\rho_{-}^{0}\left(1-\beta^{2}\right)^{-1 / 2}=-\rho_{-}$, де $\rho_{-}=\rho_{-}^{0}\left(1-\beta^{2}\right)^{-1 / 2}$ об'ємна густина заряду електронів провідності в системі

відліку $K$, в якій провідник нерухомий; v дрейфова швидкість електронів провідності; $\beta=\frac{v}{c} ; c-$ швидкість світла у вакуумі; $\rho_{-}^{0}, \rho_{+}^{0}$-густини зарядів електронів провідності і позитивних іонів у власних системах відліку відповідно $\epsilon$ непослідовною та суперечить принципу відносності. Запропоновано несуперечлива умова нейтральності провідника з постійним струмом.

Зроблено висновок щодо певної обмеженості методики навчання електродинаміки. Дійсно, закон Био-Савара и формула $\vec{E}=9 \vec{r} / 4 \pi \varepsilon_{0} r^{3}$ (очевидно являющейся следствием закона Кулона), несовместимы между собой для одновременного использования при анализе одной и той же электродинамической задачи, поскольку приводит к принципиальным ложным выводам и противоречиям. В то же время в стандартных пособиях и в научнометодических публикациях эти две формулы используются вместе, что является, с нашей точки зрения, физической ошибкой.

Ключові слова: закон Біо-Савара, умова нейтральності провідника з постійним струмом, методика навчання електродинаміки, принцип відносності. 